\title{
EFFECT OF GLUCOSE AND INSULIN ON THE ESTERIFICATION OF FATTY ACIDS BY ISOLATED ADIPOSE TISSUE*
}

\author{
By M. S. RABEN and C. H. HOLLENBERG † \\ (From the Ziskind Research Laboratories, New England Center Hospital, and the Department \\ of Medicine, Tufts University School of Medicine, Boston, Mass.)
}

(Submitted for publication September 16, 1959; accepted October 22, 1959)

Although it has been clearly demonstrated that the output of free fatty acid from adipose tissue is enhanced by fasting and reduced by giving carbohydrate (1-3), the mechanism by which nutritional alteration affects the release of fatty acids from fat depots has not been defined. The reduction in lipoprotein lipase activity of adipose tissue that occurs with fasting (4) suggests that mechanisms other than appropriate change in the activity of this enzyme causes the increased release of fatty acids from fat tissue that occurs with fasting. Experiments were performed to determine whether alterations in the esterifying function contributed to the regulation of fatty acid output. Observations were made on the net change of free fatty acids during incubation of rat epididymal fat, and on the effect of glucose and insulin on this change and on the disposition of fatty acids added to the medium.

\section{METHODS}

Pieces of epididymal fat, usually weighing 80 to 100 $\mathrm{mg}$, were removed from rats anesthetized with sodium pentobarbital, and placed in 1.0 to $1.2 \mathrm{ml}$ of medium in 25 $\mathrm{ml}$ Erlenmeyer flasks. The tissue was incubated at $37^{\circ} \mathrm{C}$ in a Dubnoff shaker with air as the gas phase. The incubation medium (unless specified otherwise) was KrebsRinger phosphate buffer containing 5 per cent human albumin. The albumin had been thoroughly pre-extracted with heptane: isopropyl alcohol: $1 \mathrm{~N}$ sulfuric acid $(10: 40: 1)$, redissolved and brought to $\mathrm{pH} 7.4$ with $\mathrm{NaOH}$. In some experiments, in order to determine the amount of acid in the adipose tissue at the start of incubation, one piece of fat was immediately weighed and ground in the extracting fluid. In all studies of pre- and postincubation values, and of the influence of various factors during incubation, multiple pieces of fat from the same animals were compared. When oleic acid was added to the medium the desired amount of a $0.1 \mathrm{M}$

* This study was supported by Grants A-1567 and A-612 from the National Institutes of Health, Bethesda, Md.

$\dagger$ Medical Research Fellow, National Research Council, Canada. solution of near-neutral sodium oleate was used. Fatty acids were extracted and titrated according to the method of Dole (1). The terms free fatty acid and fatty acid are used interchangeably in this paper and are synonomous with nonesterified fatty acid (NEFA) and unesterified fatty acid.(UFA).

\section{RESULTS}

Net change of free fatty acid during incubation of adipose tissue from fasted and fed animals. It has been shown that adipose tissue from fasted rats releases more free fatty acid into the surrounding medium during incubation than does tissue from fed animals and that gluose and insulin decrease the release of acid from fasting tissue (5). To study this phenomenon in more detail, the net change of free fatty acids during incubation was determined by comparing the fatty acid content of the tissue at the time of excision with the total amount in tissue and medium following incubation.

The accurate determination of net change of fatty acid during a period of incubation requires that the acid content of multiple pieces of fat from the same animal be reasonably constant when the various pieces are treated in a similar fashion. Table I shows the uniformity of the fatty acid content at the time of excision of multiple samples from the same animal. Similar constancy was noted when the combined values of tissue and me-

TABLE I

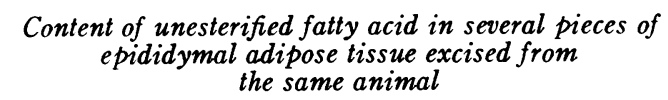
epididymal adipose tissue excised from the same animal

\begin{tabular}{clrrrr}
\hline \hline Rat & $\begin{array}{c}\text { Nutritional } \\
\text { state }\end{array}$ & \multicolumn{4}{c}{$\begin{array}{c}\text { Fatty acids in different pieces } \\
\text { of adipose tissue }\end{array}$} \\
\hline$n o$. & & \multicolumn{4}{c}{$\mu E q / g$} \\
1 & $\begin{array}{c}\text { Fasted } \\
(20 \mathrm{hrs})\end{array}$ & 12.6 & 12.5 & 12.4 & 11.8 \\
2 & $\begin{array}{c}\text { Fasted } \\
(20 \mathrm{hrs})\end{array}$ & 7.7 & 8.1 & 7.0 & 7.2 \\
3 & Fed & 4.6 & 3.7 & 3.3 & 3.1 \\
4 & Fed & 3.9 & 4.2 & 5.2 & \\
\hline
\end{tabular}


TABLE II

Net change in unesterified fatty acids during three hour incubation of epididymal adipose tissue from fasted and fed rats in Krebs-Ringer phosphate buffer containing 5 per cent albumin*

\begin{tabular}{|c|c|c|c|}
\hline $\begin{array}{l}\text { Nutritional } \\
\text { state }\end{array}$ & $\begin{array}{l}\text { Initial } \\
\text { value }\end{array}$ & $\begin{array}{l}\text { Final } \\
\text { value }\end{array}$ & $\begin{array}{c}\text { Net } \\
\text { change }\end{array}$ \\
\hline \multirow{7}{*}{ Fed } & $\mu E q / g$ & $\mu E q / g$ & $\mu E q / g$ \\
\hline & 0.5 & 3.2 & $\begin{array}{r}+2.7 \\
\end{array}$ \\
\hline & 1.4 & 3.1 & +1.7 \\
\hline & 2.3 & 4.9 & +2.6 \\
\hline & 2.7 & 1.9 & -0.8 \\
\hline & 3.9 & 2.7 & -1.2 \\
\hline & 4.1 & 3.5 & -0.6 \\
\hline Average & 2.5 & 3.2 & +0.7 \\
\hline \multirow{10}{*}{$\begin{array}{l}\text { Fasted } \\
\qquad(18-20 \mathrm{hrs})\end{array}$} & 4.9 & 9.6 & +4.7 \\
\hline & 5.1 & 7.2 & +2.1 \\
\hline & 5.9 & 11.8 & +5.9 \\
\hline & 6.3 & 8.5 & +2.2 \\
\hline & 7.0 & 11.9 & +4.9 \\
\hline & 7.5 & 6.8 & -0.7 \\
\hline & 9.3 & 11.2 & +1.9 \\
\hline & 10 & 9.6 & -0.4 \\
\hline & 10.1 & 5.1 & -5.0 \\
\hline & 10.1 & 9.2 & -0.9 \\
\hline Average & 7.6 & 9.1 & +1.5 \\
\hline
\end{tabular}

* The initial value was obtained by extraction and titration of the tissue at the time of excision and the final value from the extraction and titration of medium and tissue together at the end of incubation.

dium were determined following incubation of multiple samples from the same animal.

Although the fatty acid content of tissue and medium following incubation was greater when fasted tissue was incubated than when fed tissue was used, the initial fatty acid content of tissues from fasted (18 to 24 hours) rats was also consistently greater than that of tissues from fed rats, and therefore the net change during the incubation did not differ as much between fed and fasted tissues as would be inferred from the final value alone. With both types of tissue, the net change varied markedly, both production and loss of fatty acids being noted with tissues from both fasted and fed animals (Table II). The data in Table II suggest that the lower the initial value the greater the likelihood of production of fatty acids during incubation with both fasted and fed tissue. The fasted tissue, however, produced acid at initial concentrations of acid which would have resulted in loss of acid with fed tissue.

The presence or absence of albumin influenced the change in fatty acids during incubation. In general, it seemed from the individual changes that when production of fatty acids occurred during incubation, the magnitude of this production was greater with albumin in the medium; when a loss of acid occurred, albumin restricted the extent of this loss. This effect of albumin is probably attributable to its strong affinity for fatty acid. When acid was being produced, the albumin probably served to facilitate the transfer of fatty acid from tissue to medium, thereby preventing accumulation of acid in the tissue and thus promoting further production of acid. When esterification of

TABLE III

Loss of titratable fatty acid due to glucose and insulin during three-hour incubation of adipose tissue in Krebs-Ringer phosphate buffer*

\begin{tabular}{|c|c|c|c|c|c|c|c|c|}
\hline \multirow[b]{3}{*}{$\begin{array}{l}\text { No. of } \\
\text { rats }\end{array}$} & \multirow[b]{3}{*}{$\begin{array}{c}5 \% \\
\text { Albumin } \\
\text { in medium }\end{array}$} & \multirow{3}{*}{$\begin{array}{l}\text { Glucose } \\
200 \mathrm{mg} / \\
100 \mathrm{ml} \\
\text { Insulin } \\
10 \mathrm{mU}\end{array}$} & \multirow[b]{3}{*}{$\begin{array}{c}\text { Average } \\
\text { initial } \\
\text { value }\end{array}$} & \multirow[b]{3}{*}{$\begin{array}{l}\text { Average } \\
\text { final } \\
\text { value }\end{array}$} & \multicolumn{4}{|c|}{ Change during incubation } \\
\hline & & & & & \multirow[b]{2}{*}{ Average } & \multicolumn{3}{|c|}{ Individual rats } \\
\hline & & & & & & $\begin{array}{l}\text { Rat } \\
\text { no. } 1\end{array}$ & $\begin{array}{c}\text { Rat } \\
\text { no. } 2\end{array}$ & $\begin{array}{c}\text { Rat } \\
\text { no. } 3\end{array}$ \\
\hline \multirow{3}{*}{3} & & & \multirow{2}{*}{$\begin{array}{c}\mu E q / g \\
7.2\end{array}$} & $\mu E q / g$ & & \multicolumn{2}{|r|}{$\mu E q / g$} & \\
\hline & $\begin{array}{l}0 \\
+ \\
+\end{array}$ & $\begin{array}{l}0 \\
0 \\
+\end{array}$ & & $\begin{array}{r}6.8 \\
10.5 \\
2.4\end{array}$ & $\begin{array}{r}-0.4 \\
+3.3 \\
-4.8\end{array}$ & $\begin{array}{l}+0.7 \\
+5.9 \\
-3.3\end{array}$ & $\begin{array}{l}-0.7 \\
+2.2 \\
-4.3\end{array}$ & $\begin{array}{l}-1.2 \\
+1.9 \\
-6.8\end{array}$ \\
\hline & & & & & & $\begin{array}{c}\text { Rat } \\
\text { no. } 4\end{array}$ & $\begin{array}{c}\text { Rat } \\
\text { no. } 5\end{array}$ & $\begin{array}{c}\text { Rat } \\
\text { no. } 6\end{array}$ \\
\hline 3 & $\begin{array}{l}0 \\
0 \\
+ \\
+\end{array}$ & $\begin{array}{l}0 \\
+ \\
0 \\
+\end{array}$ & 9.0 & $\begin{array}{l}5.9 \\
1.5 \\
8.9 \\
1.7\end{array}$ & $\begin{array}{l}-3.1 \\
-7.5 \\
-0.1 \\
-7.3\end{array}$ & $\begin{array}{l}-2.3 \\
-7.9 \\
-0.4 \\
-8.4\end{array}$ & $\begin{array}{l}-7.6 \\
-9.1 \\
-5.0 \\
-8.5\end{array}$ & $\begin{array}{l}+0.6 \\
-5.7 \\
+4.9 \\
-5.2\end{array}$ \\
\hline
\end{tabular}

* Rats were fasted 18 to 20 hours. Initial and final values were obtained as in Table II. The postincubation values in this and in other tables were calculated using the final weights of the fat. The values would be approximately 20 per cent higher if calculated from initial weights since the weight of the tissue increased during incubation. 
TABLE IV

Effect of glucose and insulin on the disposition of oleic acid added to the medium*

\begin{tabular}{|c|c|c|c|c|c|}
\hline $\begin{array}{l}\text { No. of } \\
\text { rats }\end{array}$ & Glucose & Insulin & $\begin{array}{l}\text { Fatty acid } \\
\text { lost from } \\
\text { medium }\end{array}$ & $\begin{array}{l}\text { Fatty acid } \\
\text { in adipose } \\
\text { tissue after } \\
\text { incubation }\end{array}$ & $\begin{array}{c}\text { Disappeared } \\
\text { during } \\
\text { incubation }\end{array}$ \\
\hline 3 & $\begin{array}{c}m g / 100 m l \\
0 \\
0 \\
400 \\
400\end{array}$ & $\begin{array}{c}m U \\
0 \\
100 \\
0 \\
100\end{array}$ & $\begin{array}{c}\mu E q / g \\
36.4 \\
41.3 \\
37.2 \\
46.5\end{array}$ & $\begin{array}{l}\mu E q / g \\
21.0 \\
27.7 \\
15.8 \\
12.9\end{array}$ & $\begin{array}{r}\mu E q / g \\
15.4 \\
13.6 \\
21.9 \\
33.6\end{array}$ \\
\hline 2 & $\begin{array}{c}0 \\
0 \\
200 \\
200\end{array}$ & $\begin{array}{l}0 \\
1 \\
0 \\
1\end{array}$ & $\begin{array}{l}31.2 \\
36.6 \\
29.1 \\
48.0\end{array}$ & $\begin{array}{l}31.8 \\
39.6 \\
26.7 \\
18.3\end{array}$ & $\begin{array}{r}-0.6 \\
-3.0 \\
2.4 \\
29.7\end{array}$ \\
\hline 2 & $\begin{array}{c}0 \\
0 \\
100 \\
100\end{array}$ & $\begin{array}{l}0 \\
1 \\
0 \\
1\end{array}$ & $\begin{array}{l}29.7 \\
25.5 \\
27.9 \\
39.6\end{array}$ & $\begin{array}{l}26.1 \\
25.9 \\
24.9 \\
15.0\end{array}$ & $\begin{array}{r}3.1 \\
-0.4 \\
3.0 \\
24.6\end{array}$ \\
\hline
\end{tabular}

* Adipose tissue from fed rats was incubated for three hours in 1.0 to $1.2 \mathrm{ml}$ Krebs-Ringer phosphate buffer containing 5 per cent albumin and $10 \mu \mathrm{Eq}$ sodium oleate. Mean values are presented.

acid was occurring, that portion of the acid content of the tissue which rapidly entered the medium and was bound by albumin may have been relatively unavailable for esterification in the tissue. This view is consistent with the results of an experiment in which fat from three hypophysectomized animals was incubated in Krebs-Ringer phosphate buffer with 5 per cent albumin pretreated to remove fatty acids. After 20 minutes of incubation the fatty acid content of the tissue averaged $3.1 \mu \mathrm{Eq}$ per $\mathrm{g}$ and that of the medium $2.7 \mu \mathrm{Eq}$ per $\mathrm{g}$ of tissue. At the end of three hours, despite a fall in the fatty acid content of the tissue to $1.1 \mu \mathrm{Eq}$ per $g$, there was no further change in the fatty acid content of the medium.

Effect of glucose and insulin on the net change of fatty acids. When adipose tissue from rats fasted 18 to 24 hours was incubated with glucose and insulin in the medium there was regularly a decrease of fatty acids during incubation (Table III). Since glucose and insulin would not be expected to increase the catabolism of fatty acids, the increased loss of acid was thought to result from enhanced esterification. This interpretation

TABLE V

Effect of increasing amounts of insulin on disposition of oleic acid by rat epididymal adipose tissue*

\begin{tabular}{|c|c|c|c|c|c|c|}
\hline $\begin{array}{l}\text { Nutritional } \\
\text { state }\end{array}$ & $\begin{array}{l}\text { No. of } \\
\text { rats }\end{array}$ & Glucose & Insulin & $\begin{array}{l}\text { Fatty acid } \\
\text { lost from } \\
\text { medium }\end{array}$ & $\begin{array}{l}\text { Fatty acid } \\
\text { in adipose } \\
\text { tissue after } \\
\text { incubation }\end{array}$ & $\begin{array}{c}\text { Disappeared } \\
\text { during } \\
\text { incubation }\end{array}$ \\
\hline $\begin{array}{l}\text { Fasted } \\
\qquad(18 \mathrm{hrs})\end{array}$ & 2 & $\begin{array}{c}m g / 100 m l \\
100 \\
100 \\
100 \\
100\end{array}$ & $\begin{array}{l}\quad m U \\
\quad 0 \\
0.003 \\
0.03 \\
0.3\end{array}$ & $\begin{array}{l}\mu E q / g \\
40 \\
31.5 \\
54.5 \\
42\end{array}$ & $\begin{array}{c}\mu E q / g \\
24 \\
18.5 \\
13.5 \\
7.2\end{array}$ & $\begin{array}{l}\mu E q / g \\
16 \\
13 \\
41 \\
34.8\end{array}$ \\
\hline Fed & 2 & $\begin{array}{l}100 \\
100 \\
100 \\
100\end{array}$ & \begin{tabular}{l}
\multicolumn{1}{c}{0} \\
0.003 \\
0.03 \\
0.3
\end{tabular} & $\begin{array}{l}22.7 \\
21.2 \\
33.3 \\
22.1\end{array}$ & $\begin{array}{r}12 \\
12.9 \\
6.6 \\
6.6\end{array}$ & $\begin{array}{r}10.8 \\
8.7 \\
26.7 \\
15.5\end{array}$ \\
\hline $\begin{array}{l}\text { Fasted } \\
\quad(18 \mathrm{hrs})\end{array}$ & 2 & $\begin{array}{l}100 \\
100 \\
100 \\
100\end{array}$ & $\begin{array}{l}\quad 0 \\
0.003 \\
0.03 \\
0.3\end{array}$ & $\begin{array}{l}52.9 \\
54.5 \\
53.5 \\
52.1\end{array}$ & $\begin{array}{l}41.5 \\
36.3 \\
37.9 \\
21.1\end{array}$ & $\begin{array}{l}11.4 \\
18.1 \\
15.6 \\
31\end{array}$ \\
\hline
\end{tabular}

* The glucose concentration was kept constant. Incubations were carried out for two hours in 1.0 to $1.2 \mathrm{ml} \mathrm{Krebs-}$ Ringer phosphate buffer containing 5 per cent albumin and $10 \mu \mathrm{Eq}$ sodium oleate. 


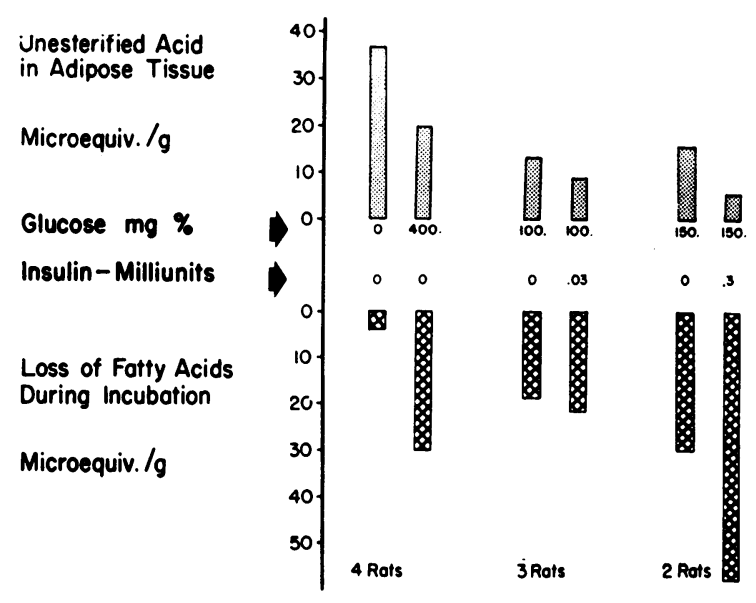

Fig. 1. EFfect of GLUCose ANd InSUlin on the disPOSITION OF OLEIC ACID $\left(10 \mu \mathrm{E}_{Q}\right)$ AdDED tO THE MEDIUM. Adipose tissue from hypophysectomized rats was incubated for 1.5 hours in the middle experiment and for 3 hours in the other two experiments. The upper bars indicate the amount of fatty acid in the adipose tissue after incubation; the lower bars indicate the amount of acid disappearing during the incubation.

was supported by experiments in which the effect was magnified by the addition of fatty acid to the medium.

After incubation of tissue in $1.0 \mathrm{ml}$ of KrebsRinger phosphate containing 5 per cent albumin and $10 \mu \mathrm{Eq}$ oleic acid, the concentrations of fatty acids in the tissue and in the medium were determined separately and the amount which left the medium and the amount of acid unaccounted for in either medium or tissue were calculated. The concentration of acid in the tissue at the end of incubation was three or four times that in the medium and there was usually a disappearance of some acid (Table IV). The acid content of the tissue at the start of incubation was not included in the calculation and the amount unaccounted for was therefore actually greater than was estimated. The effect of glucose and insulin was to decrease the concentration of free acid in the tissue and to increase the loss of acid during incubation (Tables $\mathrm{IV}$ and $\mathrm{V}$ and Figure 1). The amount of acid transferred from medium to tissue was regularly increased only with the larger amounts of glucose and insulin, when the promotion of esterification and the consequent fall in tissue content of acid was sufficient to hasten the transfer of acid from medium to tissue. Glucose alone in adequate concentrations promoted esterification. The ef- fect of insulin was seen in the presence of glucose and occurred with as little as $30 \mu \mathrm{U}$ (Table $\mathrm{V}$ and Figure 1).

\section{DISCUSSION}

The determination of net changes of free acids provides information which cannot be inferred from studying the disposition of labeled fatty acid because of the likelihood of exchange reactions between triglyceride fatty acid and free acid in the presence of lipoprotein lipase (6). In these studies a net disappearance of naturally-occurring fatty acid was promoted in incubating adipose tissue by glucose and insulin, and the loss was still greater when more fatty acid was added. The results imply that the metabolism of carbohydrate may restrict the output of free fatty acids by adipose tissue by promoting esterification and thus limiting the accumulation of free acid within the tissue. This would permit a reduction of output of fatty acids without diminished lipolysis of triglycerides. If the release of fatty acids is also influenced by alterations in lipolytic activity, it would appear to be by means other than changes in lipoprotein lipase, since fasting adipose tissue has less lipoprotein lipase activity than has fed, and since glucose and insulin prevent the decrease of lipase activity which otherwise occurs during incubation (4). The results observed here agree with the suggestion of Shapiro, Chowers and Rose (7) that adipose tissue from fed, and especially from re-fed, rats esterifies fatty acids more readily than does tissue from fasted animals. In view of the report by Hirsch, Lossow and Chaikoff (8) that glucose stimulated the esterification of fatty acids by slices of rat mammary gland, it is possible that carbohydrate metabolism promotes esterification of fatty acids in a number of tissues and thus restricts the metabolism of fat both by decreasing the output of fatty acids by adipose tissue and by favoring storage rather than use of the available acids in other tissues.

\section{SUMMARY}

Glucose alone or insulin in the presence of glucose caused a loss of naturally-occurring free fatty acids during incubation of rat epididymal adipose tissue and caused the disappearance of still greater amounts of acid when oleic acid was added to the 
medium. The metabolism of carbohydrate thus appeared to promote the esterification of fatty acids in adipose tissue and this effect may explain the reduced mobilization of fatty acids which occurs in vivo when carbohydrate is available.

\section{ACKNOWLEDGMENT}

We are grateful to Miss Mary E. Pasciuto for her assistance in this study.

\section{REFERENCES}

1. Dole, V. P. A relation between non-esterified fatty acids in plasma and the metabolism of glucose. J. clin. Invest. 1956, 35, 150.

2. Gordon, R. S., Jr., and Cherkes, A. Unesterified fatty acid in human blood plasma. J. clin. Invest. 1956, 35, 206.
3. Gordon, R. S., Jr. Unesterified fatty acid in human blood plasma. II. The transport function of unesterified fatty acid. J. clin. Invest. 1957, 36, 810.

4. Hollenberg, C. H. Effect of nutrition on activity and release of lipase from rat adipose tissue. Amer. J. Physiol. 1959, 197, 667.

5. Gordon, R. S., Jr., and Cherkes, A. Production of unesterified fatty acids from isolated rat adipose tissue incubated in vitro. Proc. Soc. exp. Biol. (N. Y.) 1958, 97, 1950.

6. Borgstrom, B. in Chemistry of Lipides as Related to Atherosclerosis, I. H. Page, Ed. Springfield, Ill., C. C Thomas, 1958, p. 186.

7. Shapiro, B., Chowers, I., and Rose, G. Fatty acid uptake esterification in adipose tissue. Biochim. biophys. Acta 1957, 23, 115.

8. Hirsch, P. F., Lossow, W. J., and Chaikoff, I. L. Effect of glucose on fatty acid and glyceride synthesis in rat mammary gland. J. biol. Chem. 1956, 221, 509. 